\title{
Impairment of insulin-stimulated GLUT4 translocation in skeletal muscle and adipose tissue in the Tsumura Suzuki obese diabetic mouse: a new genetic animal model of type 2 diabetes
}

Toshihiro Miura, Wataru Suzuki ${ }^{1}$, Eriko Ishihara, Ichiro Arai ${ }^{1}$, Hitoshi Ishida ${ }^{2}$, Yutaka Seino ${ }^{3}$ and Keiichiro Tanigawa

Department of Clinical Nutrition, Suzuka University of Medical Science, Faculty of Health Science, 1001-1 Kishioka-cho, Suzuka, Mie 510-0293,

${ }^{1}$ Tsumura Central Research Laboratories, Tsumura and Co., 3586 Yoshiwara, Ami-machi, Inashiki-gun, Ibaraki 300-11, ${ }^{2}$ Third Department of Internal Medicine, Kyorin University School of Medicine, 6-20-2 Shinkawa, Mitaka, Tokyo 181-8611 and ${ }^{3}$ Department of Metabolism and Clinical Nutrition, Kyoto University Faculty of Medicine, 54 Shogoin Kawahara-cho, Sakyo-ku, Kyoto 606, Japan

(Correspondence should be addressed to Toshihiro Miura; Email: miura@suzuka-u.ac.jp)

\begin{abstract}
Background: In skeletal muscle and adipocytes, insulin-stimulated glucose transport has been known to occur through the translocation of glucose transporter (GLUT) 4 from the intracellular pool to the plasma membrane. The Tsumura Suzuki obese diabetic (TSOD) mouse, a new genetic animal model of type 2 diabetes, develops moderate degrees of obesity and diabetes that are especially apparent in animals more than 11 weeks old. A defect in insulin stimulation of GLUT4 translocation also contributes to the characteristics of type 2 diabetes.

Objective: To characterize this mouse further, we examined the alteration in insulin-stimulated GLUT4 translocation in the skeletal muscle and adipose tissue.

Methods: For glucose and insulin tolerance tests, the mice were given glucose or insulin and blood samples were collected. After isolation of low-density microsomal membrane and plasma membrane from skeletal muscle and adipose tissue, insulin-stimulated translocation of GLUT4 in these TSOD mice was examined by Western blot.

Results and Conclusions: TSOD mice showed a significant increase in blood glucose after the glucose load, and exhibited a significantly attenuated decrease in blood glucose concentrations after administration of insulin, compared with that in control Tsumura Suzuki non-obese (TSNO) mice. The insulinstimulated translocation of GLUT4 from low-density microsomal membranes to plasma membrane was significantly reduced in both skeletal muscle and adipose tissue of TSOD mice. These results indicate that the reduced insulin sensitivity in diabetic TSOD mice is presumably due, at least in part, to the impaired GLUT4 translocation by insulin in both skeletal muscle and adipocytes.
\end{abstract}

European Journal of Endocrinology 145 785-790

\section{Introduction}

Insulin resistance in skeletal muscle and fat tissue is known to be both a predisposing factor and an underlying feature of type 2 diabetes. These broad characteristics have attracted increased research interest in the pathology of insulin resistance, in an effort to improve understanding of type 2 diabetes.

Many animal models have contributed to the elucidation of human diabetic syndromes and associated genetic factors. However, it is likely that the more distinctive characteristics of individual animal models will explain the complexities of the diabetic condition. Mouse strain models of spontaneous diabetes have been reported previously $(1-3)$, but, as individual strains exhibit different aspects of the disease process and are thus not satisfactory for general use in the study of diabetes, new models of diabetes are still sought.

The Tsumura Suzuki obese diabetic (TSOD) mouse strain, a new genetic model of type 2 diabetes, develops moderate degrees of obesity and diabetes that are especially apparent in animals more than 11 weeks old. Phenotypic characterization revealed that the TSOD mouse had reduced insulin sensitivity (4). Using a whole-genome scan of quantitative trait loci affecting body weight, blood glucose and insulin concentrations, Hirayama et al. (5) have identified three major loci meeting the rigorous criteria for linkage.

Skeletal muscles and adipocytes have been shown to express glucose transporter (GLUT) 4 and have the unique machinery required for the movement of 
GLUT4 from intracellular pools to the plasma membrane $(6,7)$. This translocation process is stimulated by insulin and accounts for a significant part of the action of insulin in peripheral tissues in maintaining glucose homeostasis. Defects in insulin stimulation of GLUT4 translocation also contribute to the characteristics of type 2 diabetes $(8,9)$. Although the exact molecular and cellular mechanisms involved in insulinstimulated GLUT4 translocation remain unclear, this process requires activation of phosphatidylinositol 3-kinase and serine/threonine phosphorylation events (10-14).

In the present study, we examined the altered insulinstimulated GLUT4 translocation in the skeletal muscle and adipose tissue of this mouse model, in order to characterize it further.

\section{Materials and methods}

\section{Animals}

Male TSOD and control Tsumura Suzuki non-obese (TSNO) mice (11 weeks old; Clea, Japan) were kept in an experimental animal room for 10 weeks with free access to food and water. They were housed individually in an air-conditioned room at an ambient temperature of $22 \pm 2{ }^{\circ} \mathrm{C}$ with a 12 -h light:12-h darkness cycle.

\section{Tolerance tests}

To test glucose tolerance, after an $18 \mathrm{~h}$ fast the TSOD and TSNO mice were given glucose $(2 \mathrm{~g} / \mathrm{kg})$ orally, and blood samples were collected $0,30,60$ and $120 \mathrm{~min}$ later.

Similarly, to test insulin tolerance, after an $18 \mathrm{~h}$ fast the two groups of mice were given insulin $(0.5 \mathrm{U} / \mathrm{kg})$ subcutaneously, and blood samples were collected 0 , 30, 60 and $120 \mathrm{~min}$ later.

\section{Determination of blood glucose and insulin}

Blood samples were taken from the cavernous sinus with a capillary syringe for determination of blood glucose concentration. Five animals were used for each treatment group. Blood glucose concentrations were determined by the glucose oxidase method (15) and serum insulin was measured by radioimmunoassay using the double-antibody method (16).

\section{Isolation of epididymal adipocytes and hindlimb muscle}

The mice were given insulin $(0.5 \mathrm{U} / \mathrm{kg})$ or saline (control) subcutaneously and, $0.5 \mathrm{~h}$ later, the hindlimb muscle and epididymal adipocytes were resected for the experiment.

\section{Low-density microsome and plasma membrane fraction of skeletal muscle}

The muscle tissue was placed in buffer $(5 \mathrm{mM}$ sodium azide, $0.25 \mathrm{M}$ sucrose, $0.1 \mathrm{mM}$ phenylmethylsulfonyl fluoride (PMSF), $10 \mathrm{mM} \mathrm{NaHCO}_{3}$, pH 7.0) at $4{ }^{\circ} \mathrm{C}$. Subfractionation of muscle membrane was as described by Baron et al. (17), whose procedure was modified from that of Klip et al. $(18,19)$. The muscle was homogenized and centrifuged at $1000 \mathrm{~g}$ for $10 \mathrm{~min}$, and the supernatant saved. The resulting pellet was resuspended in the buffer and rehomogenized in a glass homogenization tube. The supernatant was combined with the first supernatant, and centrifuged at $9000 \boldsymbol{g}$ for $10 \mathrm{~min}$. The resulting supernatant was then centrifuged at $190000 \mathrm{~g}$ for $60 \mathrm{~min}$. These membranes were applied to a discontinuous sucrose gradient containing 25,30 and $35 \%$ sucrose (wt/vol) solutions and was centrifuged at $190000 \mathrm{~g}$ for $16 \mathrm{~h}$. Membranes were collected from the top of each sucrose gradient, resuspended in the buffer, pelleted by centrifugation at $190000 \boldsymbol{g}$ for $60 \mathrm{~min}$, and resuspended in the buffer.

\section{Low-density microsome and plasma membrane fraction of adipocytes}

Low-density microsomes and plasma membranes were prepared by differential ultracentrifugation as described by Simpson et al. (20) and Smith et al. (21). The adipocyte tissue was homogenized in a buffer containing $20 \mathrm{mM}$ Tris, $1 \mathrm{mM}$ EDTA, and 0.25 M sucrose, pH 7.4. All steps were carried out at $4{ }^{\circ} \mathrm{C}$ using this buffer. The homogenate was centrifuged for $2 \mathrm{~min}$ at $6000 \mathrm{~g}$. The fat-free cell homogenate was withdrawn from under the fat layer and centrifuged for $15 \mathrm{~min}$ at $31000 \mathrm{~g}$. The supernatant was decanted and saved for preparation of the microsomal membrane fractions. The pellet was resuspended and centrifuged at $800 \boldsymbol{g}$ for $10 \mathrm{~min}$, and the supernatant obtained was centrifuged at $31000 \mathrm{~g}$ for $20 \mathrm{~min}$. The pellet was resuspended and the plasma membrane fraction was obtained by centifugation at $95000 \boldsymbol{g}$ for $60 \mathrm{~min}$ on a $32 \%$ sucrose cushion. The plasma membrane pellet was resuspended in buffer containing a protease inhibitor $(400 \mu \mathrm{M}$ plasma membrane SF). The low-density microsomal membrane fraction was obtained from the initial supernatant first by centrifugation at $65000 \mathrm{~g}$ for $15 \mathrm{~min}$, and then by recentrifugation of the $65000 \mathrm{~g}$ supernatant at $210000 \boldsymbol{g}$ for $75 \mathrm{~min}$. The latter pellet, the low-density microsomal membrane fraction, was resuspended in buffer containing the protease inhibitor.

\section{Western blot analysis}

The antibody used in the western blotting (East Acres, USA) was raised against a synthetic peptide corresponding to the COOH-terminal domain of mouse GLUT4 (12 amino acid peptide), as reported by James et al. (22) (no 
reaction against brain, or liver; does not cross-react with GLUT1 or GLUT2). To prepare the total membrane particulate fractions, the muscle and fat were excised and $1-2 \mathrm{~g}$ of each fat and muscle slice was homogenized in $25 \mathrm{ml} 10 \mathrm{mM}$ Tris $\mathrm{HCl}, 1 \mathrm{mM}$ PMSF and 1000 units/ml aprotinin (23). The homogenates were then centrifuged at $700 \mathrm{~g}$ for $10 \mathrm{~min}$ at $4^{\circ} \mathrm{C}$ to sediment the fraction containing mainly the nuclei and mitochondria. The resulting supernatant was centrifuged at $13000 \mathrm{~g}$ for $20 \mathrm{~min}$ at $4^{\circ} \mathrm{C}$ to yield a pellet designated as the membrane fraction of the liver in this study. The membrane fractions $(0.1 \mathrm{mg})$ prepared were suspended in 1\% SDS and $50 \mathrm{mM}$ dithiothreitol and subjected to SDS-polyacrylamide (9\%) gel electrophoresis. Electrophoretic transfer to nitrocellulose paper and detection of the immunocomplex with enhanced chemiluminescence (Amersham, Amersham, Bucks, UK) were carried out as described previously (24). The sheet was exposed on RX X-ray film with an intensifying screen (Fuji, Tokyo, Japan). Prestained molecular weight standards (Bio-Rad, Richmond, VA, USA) were used for estimation of the molecular weight. The experiments were performed at least twice for each tissue, with similar results.

\section{Statistical analysis}

All data are expressed as means \pm S.E.M. Paired and unpaired Student's t-test were used for the statistical analysis. Values were considered to be significantly different when $P$ was less than 0.05 .

\section{Results}

\section{Glucose tolerance test}

As shown in Table 1, body weight and blood glucose and insulin concentrations at baseline were significantly increased in diabetic TSOD mice $(P<0.01)$.

Blood glucose concentrations during the glucose tolerance test are shown in Fig. 1. The TSOD mice showed a significant increase in blood glucose concentrations 30, 60 and $120 \mathrm{~min}$ after the loading of glucose, as compared with the TSNO mice (all $P<0.05$; Fig. 1).

Table 1 Body weight, blood glucose and insulin.

\begin{tabular}{llll}
\hline & $\begin{array}{c}\text { Body weight } \\
(\mathrm{g})\end{array}$ & $\begin{array}{c}\text { Blood glucose } \\
(\mathrm{mg} / \mathrm{dl})\end{array}$ & \multicolumn{1}{c}{$\begin{array}{c}\text { Insulin } \\
(\mu \mathrm{U} / \mathrm{ml})\end{array}$} \\
\hline TSNO & $39.2 \pm 0.7$ & $166 \pm 7$ & $30 \pm 2$ \\
TSOD & $56.6 \pm 1.2^{* * *}$ & $495 \pm 26^{* *}$ & $177 \pm 12^{* * *}$
\end{tabular}

Values are means \pm S.E. from five mice.

${ }^{\star \star} P<0.01,{ }^{* \star \star} P<0.001$, significantly different from TSNO.

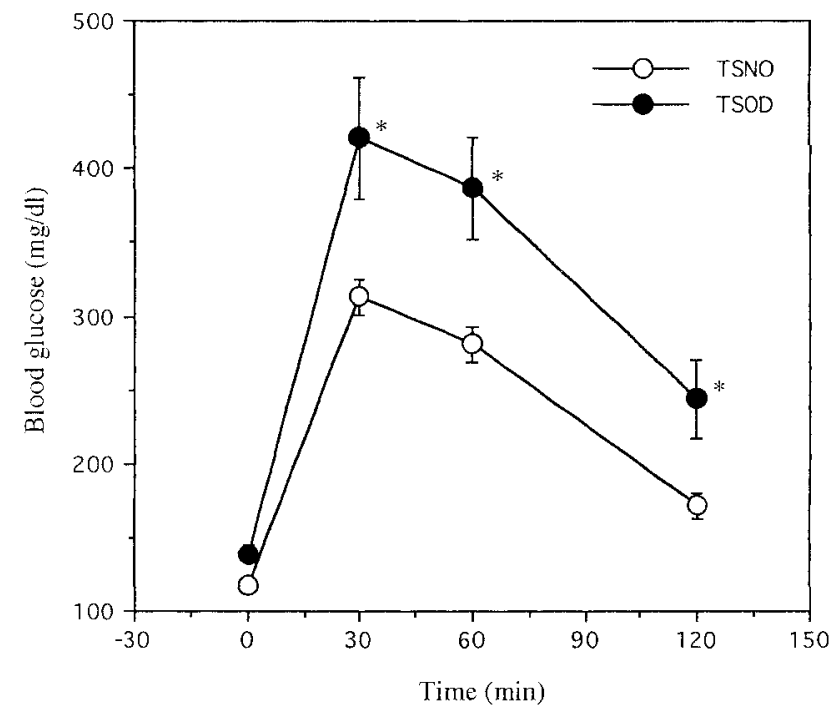

Figure 1 Glucose tolerance test. Glucose $(2 \mathrm{~g} / \mathrm{kg})$ were administered orally to TSNO and TSOD mice. Blood samples were taken for glucose determinations. Data shown are means \pm S.E.M.; results are from six animals per group. ${ }^{*} P<0.05$, significantly different from TSNO mice.

\section{Insulin tolerance test}

The subcutaneous administration of insulin $(0.5 \mathrm{U} / \mathrm{kg})$ significantly reduced blood glucose in control TSNO mice after the subcutaneous administration (30 and $60 \mathrm{~min}, P<0.001$ ), whereas the percent decrease in blood glucose was significantly reduced in TSOD mice compared with that in TSNO mice (Fig. 2), indicating the reduced insulin sensitivity in peripheral tissues in TSOD mice.

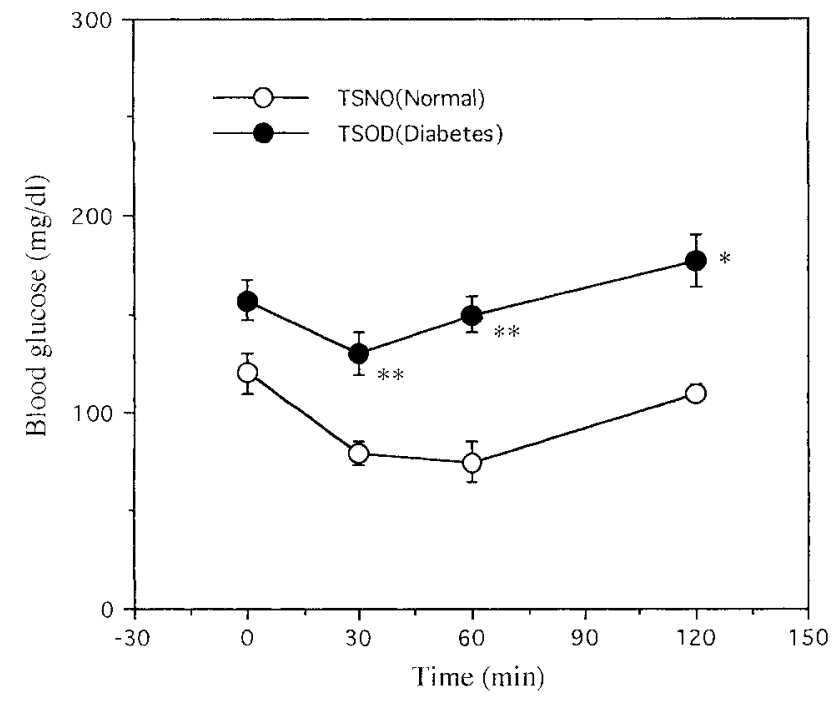

Figure 2 Insulin tolerance test. Insulin $(0.5 \mathrm{U} / \mathrm{kg})$ were administered subcutaneously to TSNO and TSOD mice. Blood samples were taken for glucose determinations. Data shown are means \pm S.E.M.; results are from six animals per group. ${ }^{*} P<0.01$, ${ }^{\star \star} P<0.001$, significantly different from TSNO mice. 

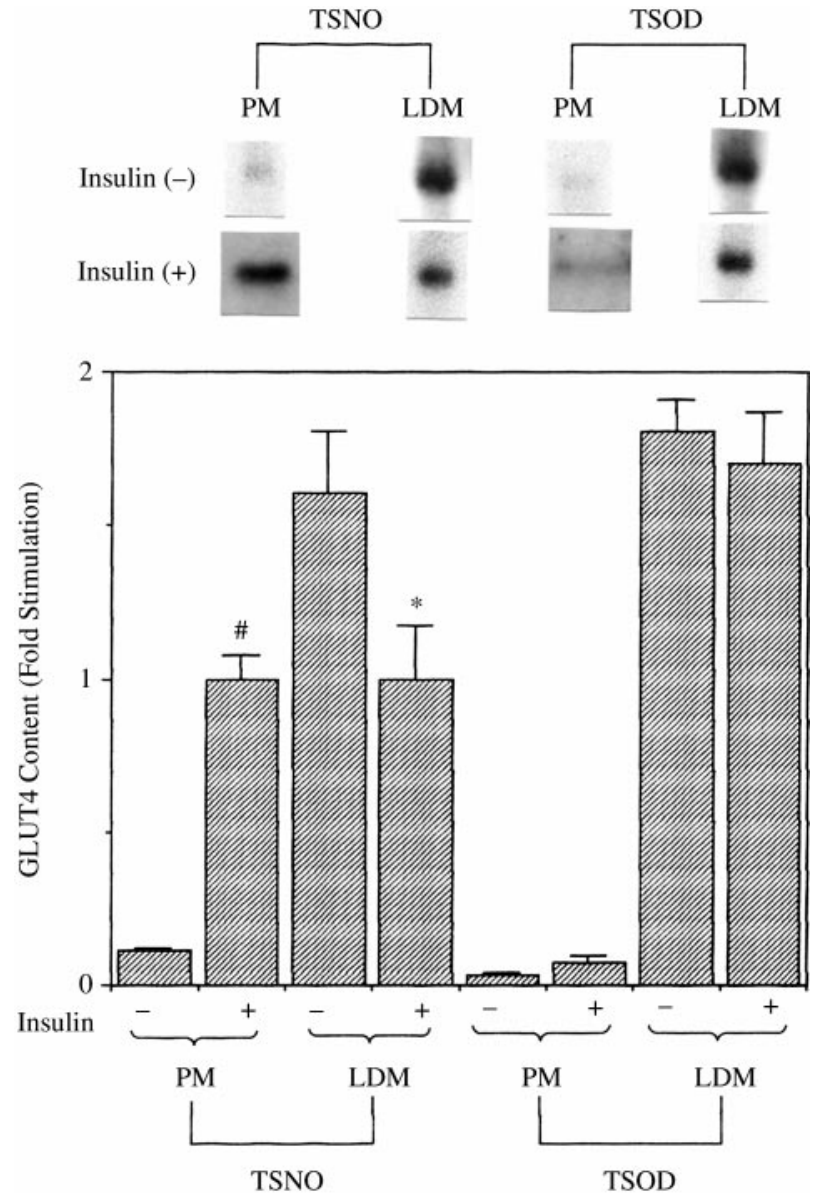

Figure 3 Subcellular distribution of GLUT4 protein in insulinstimulated muscle from TSNO and TSOD mice. PM (plasma membrane) and LDM (low-density microsome) fractions were prepared from muscle treated with insulin or saline, and GLUT4 was detected by Western blot as described in Materials and methods. Quantitation of the amount of GLUT4 in intracellular fractions from muscle is shown; values are means \pm S.E.M. of five independent experiments. $\# P<0.05,{ }^{*} P<0.01$, significantly different from TSNO mice (insulin $(-)$ ).

\section{Muscle GLUT4 protein}

Effects of exogenous insulin on muscle plasma membrane and low-density microsomal fraction of GLUT4 protein concentrations in TSOD and TSNO mice are demonstrated in Fig. 3. Insulin $(0.5 \mathrm{U} / \mathrm{kg})$ significantly increased the plasma membrane fraction of GLUT4 protein, and simultaneously decreased the low-density microsome fraction of GLUT4 protein in control TSNO mice $(P<0.05$ and $P<0.01$ in plasma membrane and low-density microsome fractions respectively), but not in diabetic TSOD mice. Consequently, the ratio of plasma membrane GLUT4 protein after insulin stimulation to that before was significantly greater in skeletal muscle of TSNO mice than in that of TSOD mice $(9.1 \pm 0.1$ in TSNO mice and $2.3 \pm 0.1$ in TSOD mice; $P<0.001)$. The percent decrease in low-density micro-
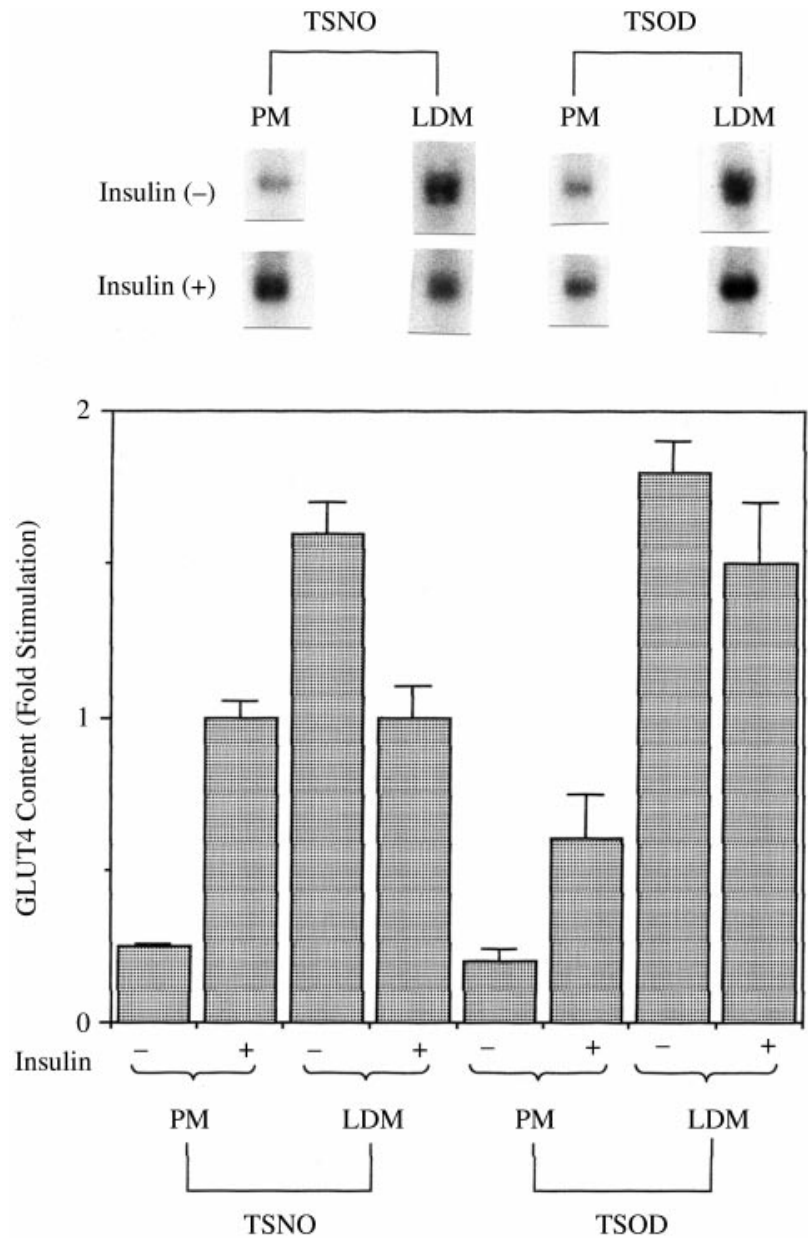

Figure 4 Subcellular distribution of GLUT4 protein in insulinstimulated adipocytes from TSNO and TSOD mice. Plasma membrane (PM) and low density microsome (LDM) fractions were prepared from adipocytes treated with insulin or saline, and GLUT4 was detected by Western blot as described in Materials and methods. Quantitation of the amount of GLUT4 in intracellular fractions from adipocytes are shown; values are means \pm S.E.M. of five independent experiments. $\# P<0.05,{ }^{*} P<0.01$, significantly different from TSNO mice (insulin (-)).

some GLUT4 by insulin stimulation was also significantly reduced in TSOD mice compared with that in TSNO mice $(6.1 \pm 0.3 \%$ and $37.9 \pm 1.6 \%$ respectively; $P<0.001)$.

\section{Adipocytes GLUT4 protein}

Figure 4 shows the effects of exogeneous insulin on the concentrations of GLUT4 proteins in plasma membrane and low-density microsome fractions from adipocytes of TSOD and TSNO mice. Insulin $(0.5 \mathrm{U} / \mathrm{kg})$ significantly increased GLUT4 protein in the plasma membrane fraction and decreased GLUT4 protein in the low-density microsome fraction of control TSNO mice $(P<0.05$ and $P<0.01$ in plasma membrane and low-density 
microsome fractions respectively), but not of diabetic TSOD mice. The ratio of plasma membrane GLUT4 protein after insulin stimulation to that before was significantly greater in adipocytes of TSNO mice than in those of TSOD mice $(4.0 \pm 0.1$ in TSNO mice and 3.0 \pm 0.1 in TSOD mice; $P<0.001)$. The percent decrease in low-density microsome GLUT4 in response to insulin administration was also smaller in TSOD mice than in TSNO mice (16.7 $\pm 0.4 \%$ and $37.5 \pm 0.9 \%$ respectively; $P<0.001)$.

\section{Discussion}

In this study, we analyzed GLUT4 concentrations in plasma membrane and low-density microsome fractions of muscle and adipocytes to clarify the pathophysiology of the insulin resistance of type 2 diabetes in TSOD mice. The TSOD mice exhibited obesity, hyperglycemia and hyperinsulinemia (Table 1), confirming the observation reported by Suzuki et al. (4). Glucose tolerance in the TSOD mice deteriorated, a decreased glucose disposal being observed in TSOD mice through the course of the insulin tolerance test (Fig. 2). These results indicate that the TSOD mouse is an animal model of typical type 2 diabetes.

It is known that, in response to insulin stimulation, GLUT4 translocates from a low-density microsome membrane to the plasma membrane fraction, permitting the entry of glucose into myocytes and adipocytes. Our study demonstrates that the TSOD mouse exhibits a decrease in the insulin-induced GLUT4 translocation in both adipose tissue and skeletal muscle, the decrease in translocation in skeletal muscle being clearly more than that in adipose tissue. The differences in translocation between skeletal muscle and adipose tissue remain to be elucidated.

Our findings suggest that the glucose intolerance exhibited by the TSOD mice was due to a decrease in GLUT4 translocation in both adipose tissue and skeletal muscle. Galuska et al. (9) reported that genetic ablation of GLUT4 resulted in impaired insulin tolerance and a defect of glucose metabolism in skeletal muscle. Moreover, they reported that overexpression of GLUT4 in muscle resulted in increased glucose uptake and metabolism, protecting against the development of insulin resistance in transgenic mice (9). These findings indicate that the impairment of GLUT4 translocation results in the development of insulin resistance. In addition, Garvey et al. (8) demonstrated that insulin alters the subcellular localization of GLUT4 vesicles in human muscle, and this effect was equally impaired in insulin-resistant individuals with and without diabetes. They suggested that this translocation defect was associated with abnormal accumulation of GLUT4 in a dense membrane compartment. In our study, the TSOD mouse exhibited a similar pattern of defects, causing insulin resistance.

\section{References}

1 Broinick JT, Etgen GJ, Yaspelkis BB \& Ivy JL. Glucose uptake and GLUT4 protein distribution in skeletal muscle of the obese Zucker rat. American Journal of Physiology 1994267 R236-R243.

2 King PA, Horton ED, Hirshman MF \& Horton ES. Insulin resistance in obese Zucker rat (fa/fa) skeletal muscle is associated with a failure of glucose transporter translocation. Journal of Clinical Investigation $1992901568-1575$.

3 Sherman WM, Katz AL, Culter CL, Withers RT \& Ivy JL. Glucose transport: locus of muscle insulin resistance in obese Zucker rats. American Journal of Physiology 1988255 E374-E382.

4 Suzuki W, Ilzuka S, Tabuchi M, Funo S, Yanagisawa T, Kimura M et al. A new mouse model of spontaneous diabetes derived from ddY strain. Experimental Animals 199948 181-189.

5 Hirayama I, Yi Z, Izumi S, Arai I, Suzuki W, Nagamachi Y et al. Genetic analysis of obese diabees in the TSOD mouse. Diabetes 199948 1183-1191.

6 Kennedy JW, Hirshman MF, Gervino EV, Ocel JV, Forse RA, Hoenig SJ et al. Acute exercise induces GLUT4 translocation in skeletal muscle of normal human subjects and subjects with type 2 diabetes. Diabetes $1999 \mathbf{4 8} 1192-1197$.

7 Tirosh A, Potashnik R, Bashan N \& Rudich A. Oxidative stress disrupts insulin-induced cellular redistribution of insulin receptor substrate-1 and phosphatidylinositol 3-kinase in 3T3-L1 adipocytes. A putative cellular mechanism for impaired protein kinase B activation and GLUT4 translocation. Journal of Biological Chemistry 1999274 10595-10602.

8 Garvey WT, Maianu L, Zhu JH, Brechtel-Hook G, Wallace P \& Baron AD. Evidence for defects in the trafficking and translocation of GLUT4 glucose transporters in skeletal muscle as a cause of human insulin resistance. Journal of Clinical Investigation 1998 $1012377-2386$.

9 Galuska D, Ryder J, Kawano Y, Charron MJ \& Zierath JR. Insulin signaling and glucose transport in insulin resistant skeletal muscle. Special reference to GLUT4 transgenic and GLUT4 knockout mice. Advances in Experimental Medicine and Biology 1998441 73-85.

10 Terauchi Y, Tsuji Y, Satoh S, Minoura H, Murakami K, Okuno A et al. Increased insulin sensitivity and hypoglycaemia in mice lacking the p85 alpha subunit of phosphoinositide 3-kinase. Nature Genetics 199921 230-235.

11 Anai M, Funaki M, Ogihara T, Kanda A, Onishi Y, Sakoda H et al. Enhanced insulin-stimulated activation of phosphatidylinositol 3-kinase in the liver of high-fat-fed rats. Diabetes $1999 \mathbf{4 8}$ $158-169$.

12 Chen H, Cong LN, Li Y, Yao ZJ, Wo L, Zhang ZY et al. A phosphotyrosyl mimetic peptide reverses impairment of insulin-stimulated translocation of GLUT4 caused by overexpression of PTP1B in rat adipose cells. Biochemistry 199938 384-389.

13 Zorzano A, Sevilla L, Tomas E, Camps M, Guma A \& Palacin M. Trafficking pathway of GLUT4 glucose transporters in muscle. International Journal of Molecular Medicine 19982 263-271.

14 Zierath JR, Krook A \& Wallberg-Henriksson H. Insulin action in skeletal muscle from patients with type 2 diabetes. Molecular and Cellular Biochemistry 1998182 153-160.

15 Marks V \& Lloyd K. Preservation of blood glucose analysis by glucose oxidase. Clinica Chimica Acta 19638326.

16 Tsuura Y, Ishida H, Okamoto Y, Tsuji K, Kurose T, Horie M et al. Impaired glucose sensitivity of ATP-sensive $\mathrm{K}+$ channels in pancreatic B-cells in streptozotocin-induced type 2 diabetes rats. Diabetes $199241861-865$.

17 Baron A, Zhu JS, Zhu JH, Weldon H, Maianu L \& Garvey MT. Glucosamine induces insulin resistance in vivo by affecting GLUT4 translocation in skeletal muscle. Implications for glucose toxicity. Journal of Clinical Investigation 1995 2792-2801.

18 Klip A, Ramlal T, Young DA \& Holloszy JO. Insulin-stimulated glucose transporters in rat hindlimb muscles. FEBS Letters 1987 $224224-230$.

19 Klip A, Ramlal T, Bilan PJ, Cartee GD, Gulve EA \& Holloszy JO. Recruitment of GLUT4 glucose transporter by insulin in diabetic 
rat skeletal muscle. Biochemical and Biophysical Research Communications $1990172728-736$.

20 Simpson IA, Yver DR, Hissin PJ, Wardzala LJ, Karnieli E, Salans LB et al. Insulin-stimulated translocation of glucose transporters in the isolated rat adipose cells: characterization of subcellular fractions. Biochimica et Biophysica Acta 1983763 393-407.

21 Smith MM, Robinson FW, Watanabe T \& Kondo T. Partial characterization of the glucose transport activity in the Golgirich fraction of fat cells. Biochimica et Biophysica Acta $1984 \mathbf{7 7 5}$ $121-128$.

22 James DE, Strube M \& Mueckler M. Molecular cloning and characterization of an insulin-regulatable glucose transporter. Nature $198933883-87$.
23 Oka Y, Asano T \& Shibasaki A. Increased liver glucose transporter protein and mRNA in streptozotocin-induced diabetic mice. Diabetes $199039441-446$.

24 Perez C, Albert I \& DeFay K. A nonsecretable cell surface mutant of tumor necrosis factor (TNF) kills by cell-to-cell contact. Cell 1990 $63251-258$.

Received 9 August 2001

Accepted 22 August 2001 